\title{
Strategi Peningkatan Efektivitas Masyarakat Peduli Api (MPA) Dalam Pengendalian Kebakaran Hutan di Provinsi Bali
}

\author{
DARJO $^{\left.1^{*}\right)}$, I WAYAN SUARNA ${ }^{2}$, DAN GEDE WIJANA ${ }^{1}$ \\ ${ }^{1}$ Program Studi Magister Petanian Lahan Kering, Fakultas Pertanian, Universitas Udayana \\ ${ }^{2}$ Fakultas Peternakan, Universitas Udayana \\ ${ }^{*}$ E-mail: sodagar96@gmail.com
}

\begin{abstract}
Strategy For Improving Effectiveness of Fire Care Society (MPA) in Control of Forest Fire in Bali Province. Land and forest fires seem to be an annual disaster in Indonesia. The Ministry of Environment and Forestry is initiated to form Fire Care Community Groups, called Fire Care Society (MPA). MPA in Bali has been established since 2012. The study is needed to determine the community perception who live around the forest areas, to determine the effectiveness of MPA, and to analyzed strategic increases the effectiveness of MPAregarding forest fires controlling. Research data has been collected through a closed questionnaire to compile the respond of respondents in the google form. The respondent consisted of MPA member and non-member and related stakeholders. The types of data that been collected include respondent's perceptions, MPA participation, and implementation of Perdirjen PPI number 3, 2018. These data then analyzed with the SWOT method. The results showed that the MPA and non-MPA members have positive perception of natural factor and human behavior as a factor of forest fires. The highest value of MPA's participation in fires-fighting is 3.71 and participation influenced by environmental factors valued at 3.84. While the implementation of Perdirjen PPI decree is $66.39 \%$. The SWOT analysis shows the MPA in progressive strategic S-O. So this study concludes that the MPA hasn't been fully effective. The effectiveness can be improved by providing adequate support through clear regulations, budget allocations, and increasing human resource capacity.
\end{abstract}

Keywords: MPA, Forest Fire, Perception, Participation, Strategic

\section{PENDAHULUAN}

Kebakaran hutan merupakan masalah utama di Indonesia. Meskipun bukan fenomena baru, frekuensi dan tingkat keparahannya pada satu dekade terakhir cenderung meningkat (Harrison et al.,
2009). Kebakaran hutan dianggap sebagai ancaman potensial bagi pembangunan berkelanjutan karena dampaknya secara langsung terhadap kesehatan manusia (Harrison et al., 2009; David et al., 2014; Edward et al., 2015), aktivitas 


\section{DARJO et al. Strategi Peningkatan Efektivitas Masyarakat Peduli Api (MPA)...}

perekonomian (Miettinen et al., 2017; Alisjahbana dan Busch, 2017), dan terhadap ekosistem dan lingkungannya (Tacconi, 2003; Földi dan Kuti, 2016). Dengan kata lain, kebakaran hutan memberikan dampak negatif hampir ke seluruh sektor, seperti ekonomi, sosial, kesehatan, dan lingkungan. Melihat berbagai dampak yang ditimbulkan sangat mengerikan, sehingga kebakaran hutan dan lahan menjadi masalah serius dan tidak dapat dianggap remeh. Pemerintah melalui Kementerian Lingkungan Hidup dan Kehutanan melakukan berbagai upaya untuk mengatasi kebakaran hutan termasuk dengan memperkuat pembentukan masyarakat peduli api atau MPA di berbagai daerah, salah satunya Provinsi Bali.

MPA di Provinsi Bali pertama kali dibentuk pada tahun 2012, hingga saat ini terdapat 9 kelompok MPA dengan jumlah anggota sebanyak 195 orang yang tersebar di tiga tempat, yaitu 4 di kawasan BKSDA Bali, 4 di kawasan KPH Bali Timur, dan 1 di TN Bali Barat. Dengan jumlah anggota MPA yang telah dibentuk, kejadian kebakaran hutan masih tetap terjadi dan tidak dapat diprediksi luasannya yang bervariasi setiap tahunnya. Hal tersebut menunjukkan bahwa upaya pengendalian kebakaran hutan oleh MPA belum optimal dan berhasil. Belum optimalnya MPA dalam mendukung pengendalian kebakaran hutan, dapat diketahui melalui persepsinya terhadap faktor penyebab dan kerugian akibat kebakaran hutan serta partisipasinya di lapangan. Tidak hanya MPA saja, namun penting untuk diketahui persepsi dan partisipasi masyarakat yang berdampingan dengan MPA yang merupakan desa yang rawan terhadap kebakaran hutan. Maka dari itu, tujuan dari penelitian ini untuk mengetahui persepsi masyarakat sekitar kawasan hutan terhadap kebakaran hutan, mengetahui efektivitas MPA dalam pengendalian kebakaran hutan, dan mengetahui strategi peningkatan efektivitas MPA dalam pengendalian kebakaran hutan yang ada di Provinsi Bali.

\section{BAHAN DAN METODE}

Penelitian dilakukan pada bulan April sampai Juli 2020. Lokasi dalam penelitian ini yaitu desa yang memiliki anggota MPA dan desa sekitarnya yang tidak memiliki anggota MPA yang berada di Kabupaten Buleleng, Bangli, dan Kabupaten Karangasem.

Alat dan bahan yang digunakan dalam penelitian ini antara lain alat tulis untuk mencatat, alat perekam suara untuk merekam percakapan saat wawancara, 
kamera untuk dokumentasi, Perdirjen PPI nomor 3 tahun 2018 untuk diketahui implementasinya di lapangan, kuesioner dalam bentuk google form, dan handphone untuk mengisi kuesioner, serta panduan wawancara.

Penelitian ini dilakukan dengan menggunakan kuesioner tertutup melalui google form. Hal ini disebabkan oleh karena pada saat penelitian ini berlangsung sedang terjadi pandemi COVID-19. Responden pada penelitian ini terbagi menjadi tiga, yaitu masyarakat yang menjadi anggota MPA (Desa Sumberklampok, Buahan, Batur Selatan, dan Pempatan), masyarakat non MPA (Desa Kintamani, Pejarakan, dan Besakih), dan Stakeholder (Ditjen PPI, BPPIKHL JBN, BKSDA Bali, TN Bali Barat, KPH Bali Timur, dan Kepala Desa MPA). Total responden sebanyak 192 orang terdiri atas 90 orang dari masyarakat non MPA (30 orang dari masing-masing Desa Besakih, Desa Kintamani, dan Desa Pejarakan), 75 orang masyarakat MPA (MPA Sumberklampok 15 orang, MPA Pempatan 15 orang, MPA Batur Selatan 15 orang, dan MPA Buahan 30 orang), dan 27 orang dari stakeholder (Ditjen PPI 6 orang, BPPIKHL JBN 4 orang, BKSDA Bali 7 orang, TN Bali Barat 3 orang, KPH Bali Timur 4 orang, dan Kepala Desa Buahan, Sumberklampok, dan Batur Selatan).

Data dan informasi persepsi masyarakat (MPA dan non MPA), partisipasi MPA, dan implementasi Perdirjen PPI nomor 3 tahun 2018, serta strategi pengendalian kebakaran hutan melalui analisis SWOT dikumpulkan melalui kuesioner tertutup dengan skala likert. Teknik pengambilan contoh sampelsecara purposive sampling yaitu data dan informasi dikumpulkan dari aktor-aktor kunci yang terkait dengan objek penelitian.

Analisis data persepsi masyarakat (MPA dan non MPA) dan partisipasi MPA dilakukan dengan menghitung rata-rata skoring jawaban tiap responden yang disajikan dalam bentuk grafik dan analisis deskriptif untuk menjelaskan persepsi dan partisipasinya. Analisis implementasi Perdirjen PPI nomor 3 tahun 2018 menggunakan ketidaksesuaian/gap yang muncul antara kondisi ideal dengan kenyataan di lapangan. Analisis SWOT di awali dengan dilakukannya pencarian bobot, rating, dan skor. Kemudian mencari nilai IFAS (internal strategic factor analysis summary) yang disimbolkan dengan titik $\mathrm{X}$ dan nilai EFAS (external strategic factor analysis summary) yang disimbolkan dengan titik Y. Kemudian nilai 


\section{DARJO et al. Strategi Peningkatan Efektivitas Masyarakat Peduli Api (MPA)...}

IFAS dan EFAS digambarkan dalam besar kebakaran hutan disebabkan oleh dua sebuah diagram $(\mathrm{X}, \mathrm{Y})$, dan dinarasikan faktor, yaitu manusia dan alam (Rasyid, strateginya.

\section{HASIL DAN PEMBAHASAN}

\section{Persepsi Masyarakat terhadap Faktor}

\section{Penyebab Kebakaran Hutan}

Persepsi berkaitan dengan interpretasi makna atau penafsiran informasi. Wade dan Carol (2007) menjelaskan bahwa persepsi dipengaruhi oleh kebutuhan, kepercayaan, emosi dan ekspektasi, serta adanya kebudayaan masing-masing. Secara garis 2014). Manusia secara langsung ataupun tidak langsung, sengaja ataupun tidak sengaja menjadi faktor yang paling dominan menyebabkan terjadinya kebakaran hutan (Rasyid, 2014; Nursoleha et al., 2014). Meskipun faktor alam penyebab kebakaran hutan tidak lebih dominan, namun bisa jadi itu sebagai faktor pemicu terjadinya kebakaran, sehingga harus diperhatikan.

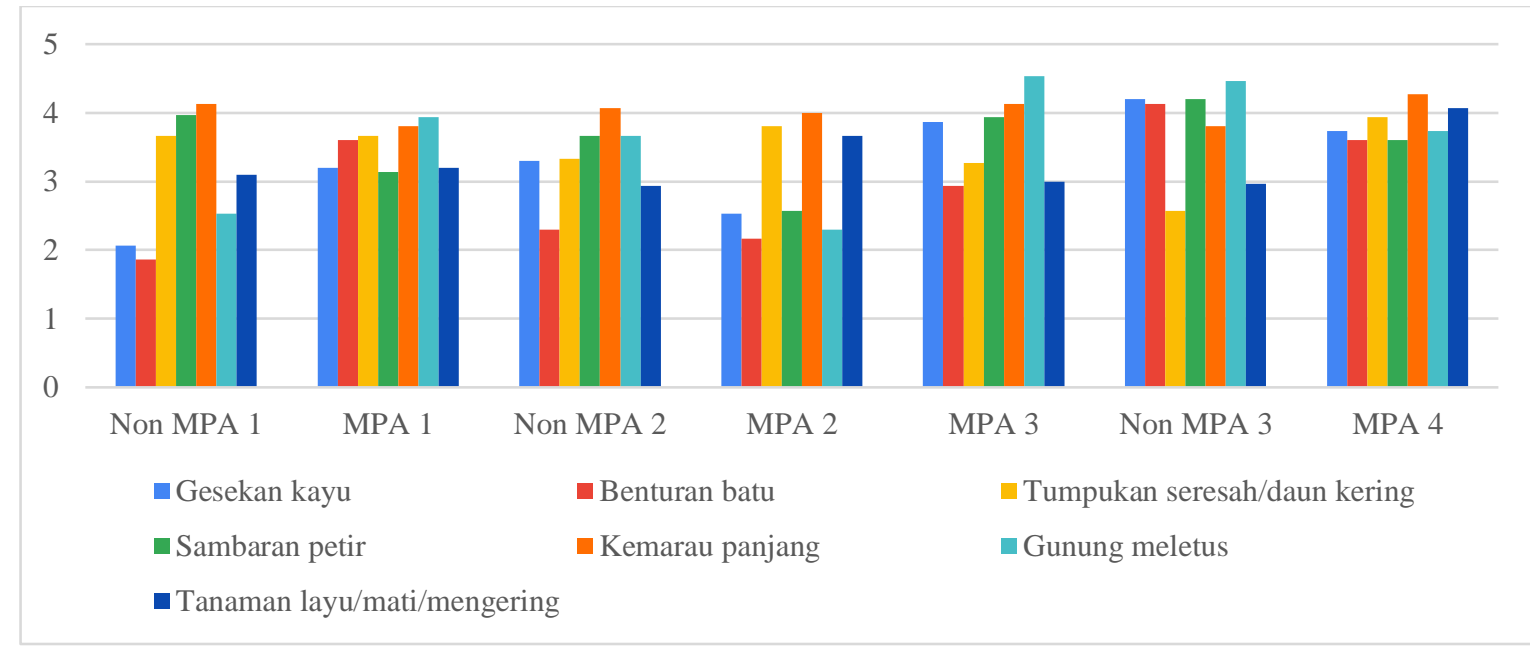

Keterangan: $\mathrm{n}=165$

Non MPA 1= Desa Pejarakan; Non MPA 2= Desa Kintamani; Non MPA 3= Desa Besakih

MPA 1= Desa Sumberklampok; MPA 2= Desa Buahan; MPA 3= Desa Batur Selatan; MPA 4= Desa Pempatan

Skor persepsi: 1 = sangat tidak setuju, 2 = tidak setuju, 3 = biasa saja, 4 = setuju, $5=$ sangat setuju

Gambar 1. Persepsi masyarakat (MPA dan non MPA) mengenai faktor alam penyebab terjadinya kebakaran hutan 
Berdasarkan hasil analisis, diketahui masyarakat (MPA dan non MPA) mempersepsikan kemarau panjang dengan nilai rerata tertinggi, 4,04 untuk masyarakat MPA dan 4,00 untuk masyarakat non MPA (Gambar 1). Tingginya persepsi terhadap kemarau panjang dikarenakan pada saat kemarau panjang ketersediaan bahan bakar melimpah. Sebagaimana dikemukakan oleh Saharjo dan Wibisana (2017) bahwa pada musim kemarau yang cukup panjang, seresah di lantai hutan menjadi kering dan bahan bakar menjadi melimpah. Bahan bakar tidak akan rentan terhadap api apabila basah dan lembab. Sehingga pada saat musim kemarau, suhu yang tinggi membuat bahan bakar tersebut akan semakinkeringdan selanjutnya menjadi mudah terbakar (Fadlillah et al., 2017). Kemarau panjang juga terjadi karena dipengaruhi adanya El-Nino. Rasyid (2014) menjelaskan bahwa saat ada El-Nino maka kemarau akan lebih panjang dibanding kemarau biasanya sehingga berpotensi menyebabkan tanaman menjadi kering dan terbakar ketika ada percikan api.
Data statistik BPPIKHL JBN (2020) menunjukkan bahwa sebagian besar kebakaran hutan di Provinsi Bali tahun 2019 terjadi pada vegetasi berupa padang rumput, semak belukar, dan tegakan cemara. Vegetasi tersebut saat kemarau, biasanya mengering, sehingga mudah sekali terbakar. Selain itu, Fadlillah et al., (2017) dalam penelitiannya juga menjelaskan bahwa pada tegakan sejenis/homogen (hanya terdapat satu spesies saja), api semakin mudah dan cepat menjalar. Kondisi ini yang menjadi salah satu penyebab pada vegetasi tersebut banyak terjadi kebakaran hutan di Provinsi Bali.

Pada faktor manusia penyebab kebakaran hutan, masyarakat anggota MPA memberikan persepsi faktor manusia penyebab kebakaran hutan berupa membuang puntung rokok sembarangan nilai tertinggi yaitu 4,17 (Gambar 2). Sedangkan pada masyarakat non MPA, membuang puntung rokok sembarangan memiliki nilai persepsi rata-rata tertinggi yaitu 4,11 . 


\section{DARJO et al. Strategi Peningkatan Efektivitas Masyarakat Peduli Api (MPA)...}

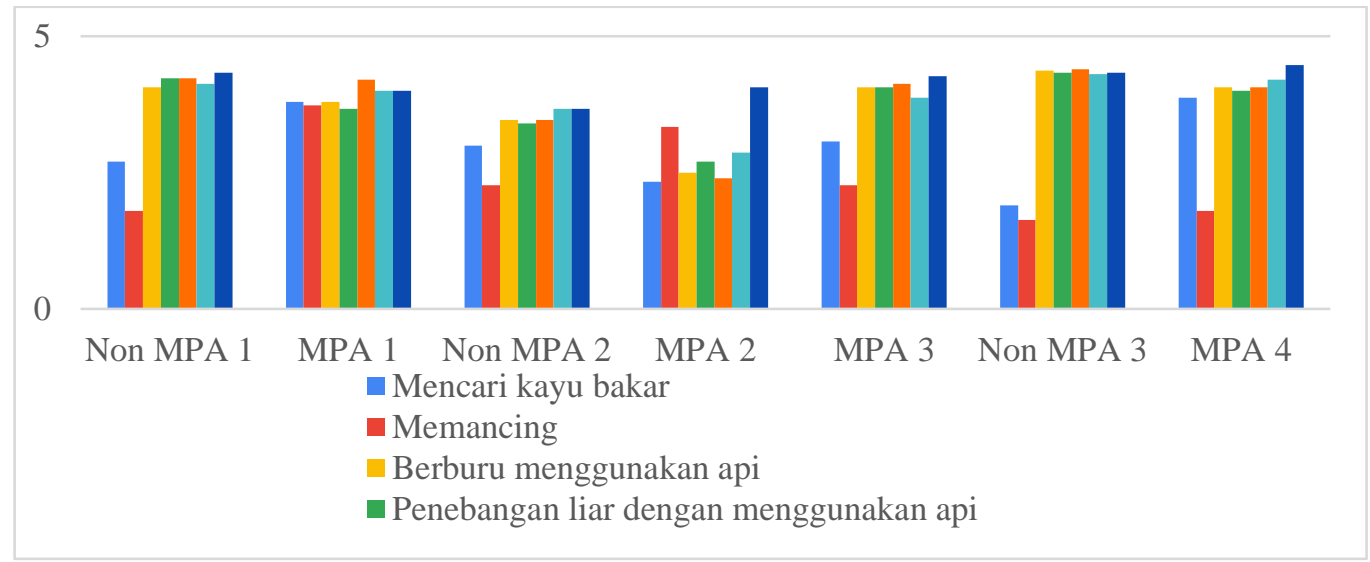

Keterangan: $\mathrm{n}=165$

Non MPA 1= Desa Pejarakan; Non MPA 2= Desa Kintamani; Non MPA 3= Desa Besakih

MPA 1= Desa Sumberklampok; MPA 2= Desa Buahan; MPA 3= Desa Batur Selatan; MPA 4= Desa Pempatan

Skor persepsi: 1 = sangat tidak setuju, 2 = tidak setuju, 3 = biasa saja, 4 = setuju, $5=$ sangat setuju

Gambar 2. Persepsi masyarakat (MPA dan non MPA) mengenai faktor manusia penyebab terjadinya kebakaran hutan

Persepsi masyarakat (MPA dan non MPA) mengenai pembuangan puntung rokok yang tidak mati sempurna sebagai salah satu penyebab terjadinya kebakaran hutan dapat dipengaruhi oleh dua hal. Pertama, persepsi tersebut muncul karena pengalaman secara langsung mengetahui kejadian kebakaran hutan di sekitar desanya yang disebabkan oleh puntung rokok. Kedua, dikarenakan pemberitaan media, baik cetak maupun daring (online), banyak yang memberitakan penyebab kebakaran karena puntung rokok yang tidak mati sempurna saat di buang (Rezkisari, 2017; Alawi, 2017; Tanjung, 2019). Kebakaran hutan akibat puntung rokok juga terjadi di
Provinsi Bali pada tahun 2017 (Suyatra, 2017).

Selain pembuangan puntung rokok yang tidak mati sempurna, penyiapan lahan dengan membakar juga dipersepsikan sebagai penyebab kebakaran hutan. Banyak penelitian diberbagai wilayah menyebutkan bahwa kebakaran hutan terjadi karena adanya kelalaian saat menyiapkan lahan dengan dibakar, sehingga menyebabkan kebakaran di wilayah lainnya. Penyiapan lahan dengan cara dibakar menjadi alternatif utama masyarakat karena alasan aspek ekonomi (Sawerahet al.,2016), yaitu paling mudah, murah, dan lebih efektif (BNPB, 2013). 
Mengenai kerugian akibat kebakaran hutan, masyarakat (MPA dan non MPA) mempersepsikan kesehatan dan lingkungan sebagai faktor yang paling terdampak akibat adanya kebakaran hutan (Gambar 3).

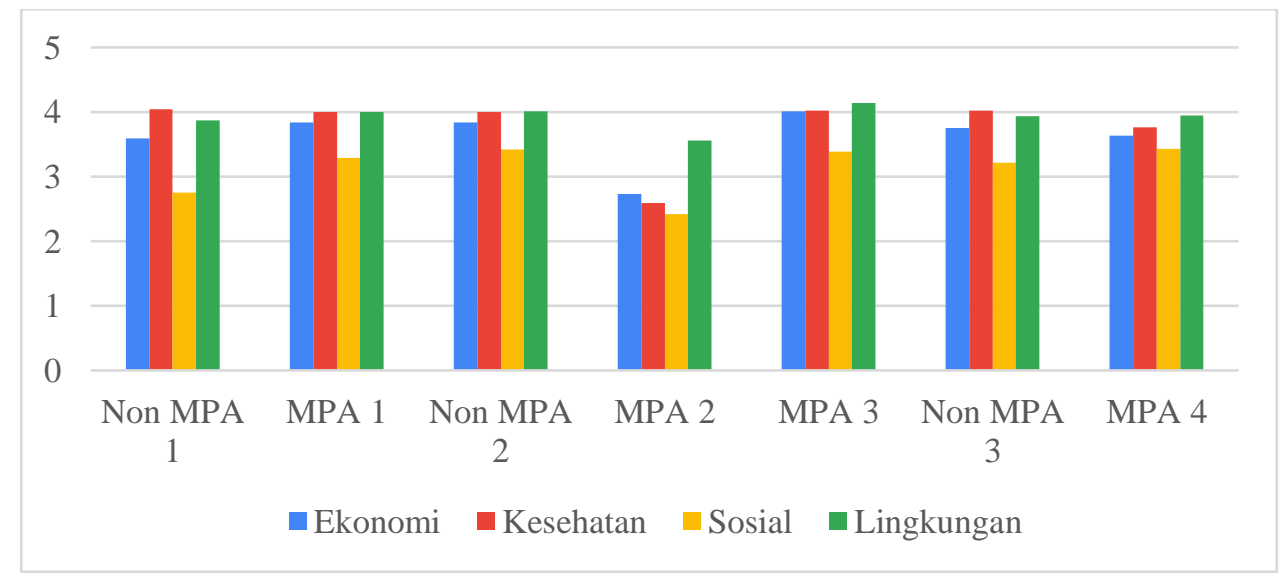

Keterangan: $\mathrm{n}=165$

Non MPA 1= Desa Pejarakan; Non MPA 2= Desa Kintamani; Non MPA 3= Desa Besakih

MPA 1= Desa Sumberklampok; MPA 2= Desa Buahan; MPA 3= Desa Batur Selatan; MPA 4= Desa Pempatan

Skor persepsi: 1 = sangat tidak setuju, 2 = tidak setuju, 3 = biasa saja, 4 = setuju, 5 = sangat setuju

Gambar 3. Persepsi masyarakat (MPA dan non MPA) mengenai kerugian akibat kebakaran hutan

Faktor lingkungan menjadi persepsi dikemukakan oleh Fadlillah et al., (2017) tertinggi karena dampak langsung yang bahwa hilangnya tutupan vegetasi akibat terjadi dan terlihat saat terjadi kebakaran. kebakaran hutan menyebabkan terjadinya Saharjo et al., (2018) menjelaskan bahwa banjir dan tanah longsor sehingga kebakaran hutan menimbulkan kerusakan fungsi hutan sebagai pengatur iklim dan menghambat aliran air dan tanah.

Faktor kesehatan menjadi faktor yang lebih jauh lagi akan merusak daerah aliran dirugikan akibat kebakaran hutan karena sungai (DAS). Kematian flora dan fauna menjadi kerugian nyata akibat terjadinya kebakaran hutan. Selain itu, kebakaran hutan juga memicu bencana lainnya, seperti longsor dan banjir. Hal ini sebagaimana masyarakat dapat merasakan secara langsung gangguan kesehatan yang dialami saat kejadian kebakaran. Gangguan pernafasan merupakan yang paling sering dialami saat kebakaran hutan, hal ini akibat 


\section{DARJO et al. Strategi Peningkatan Efektivitas Masyarakat Peduli Api (MPA)...}

berbagai senyawa kimia yang dihasilkan dari pembakaran yang tidak sempurna. Polutan kimiawi yang muncul setelah terjadi kebakaran hutan diantaranya seperti SO2, NOx, O3, CO, dan bahan partikel bersifat membahayakan bagi kesehatan manusia (Saharjo et al., 2018). Lebih lanjut Saharjo et al., (2018) menjelaskan bahwa dampak signifikan saat terjadi kebakaran hutan besar terhadap kesehatan di berbagai wilayah di Indonesia adalah infeksi saluran pernafasan akut (ISPA), bronchial asthma, diare, iritasi mata, dan penyakit kulit.

\section{Partisipasi Masyarakat MPA dalam}

\section{Pengendalian Kebakaran Hutan}

Partisipasi adalah tingkat rasa

keterlibatan dan keikatan seseorang berkat sumbangan pikiran dan usulnya sehingga mereka bertanggung jawab atas pekerjaannya sendiri dan ikut berusaha mencapai sasaran suatu tujuan organisasi (Marbun, (2003 dalam Evayanti dan Zulkarnaini, 2014)). Berdasarkan hasil kuesioner diketahui bahwa partisipasi MPA dalam pengendalian kebakaran hutan yang paling dominan pada penelitian ini adalah saat pemadaman dibandingkan pencegahan dan penanganan pasca kebakaran (Gambar 4). Hal ini disebabkan oleh karena MPA terlibat secara langsung dalam setiap pemadaman kebakaran hutan di lapangan.

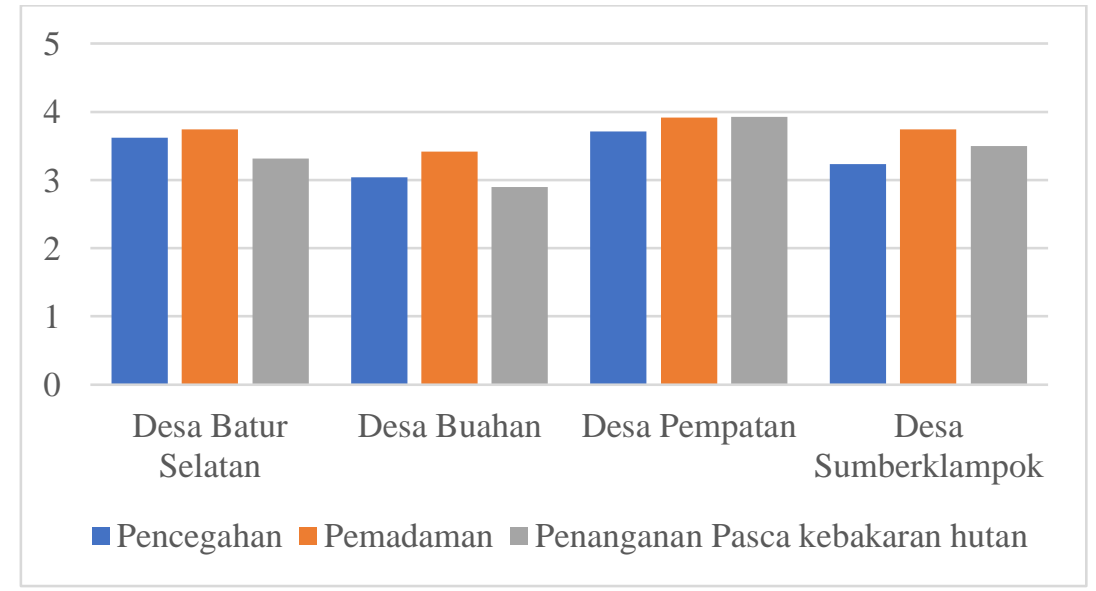

Keterangan: $\mathrm{n}=75$

Skor partisipasi: 1 = sangat tidak aktif, 2 = tidak aktif, 3 = biasa saja, 4 = aktif, 5 = sangat aktif Gambar 4. Partisipasi masyarakat MPA dalam pengendalian kebakaran hutan 
MPA merupakan garda terdepan di tingkat tapak, sehingga setiap terjadi kebakaran hutan, keberadaan MPA sangat diandalkan untuk mendukung upaya pemadaman. Tingginya tingkat partisipasi MPA saat pemadaman juga disebabkan karena sampai saat ini kegiatan pemadaman masih menjadi fokus utama kegiatan pengendalian kebakaran hutan (Fadlillahet al., 2017). MPA tidak terbatas melakukan pemadaman di lokasi sekitar desanya saja, namun terkadang juga bergabung dengan MPA desa lainnya untuk melakukan pemadaman di tempat lain. Kondisi tersebut menyebabkan partisipasi MPA pada pemadaman lebih tinggi.

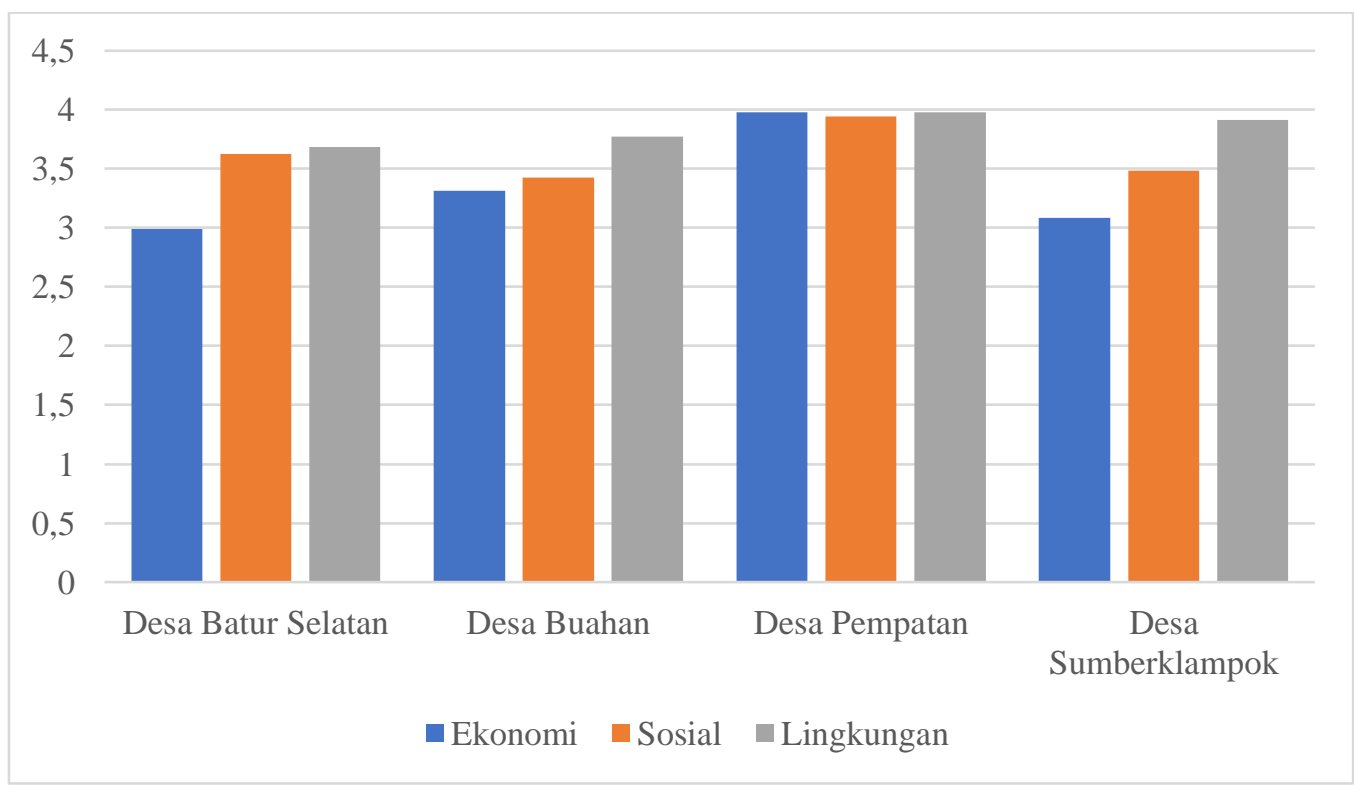

Keterangan: $\mathrm{n}=75$

Skor partisipasi: 1 = sangat rendah, $2=$ rendah, $3=$ biasa saja, $4=$ tinggi, $5=$ sangat tinggi

Gambar 5. Faktor yang memengaruhi partisipasi masyarakat MPA dalam pengendalian kebakaran hutan

Partisipasi MPA dalam pengendalian kebakaran hutan dipengaruhi oleh berbagai faktor. Pada Gambar 5 diketahui bahwa faktor lingkungan merupakan yang paling mempengaruhi tingginya partisipasi MPA di semua desa dalam pengendalian kebakaran hutan. Faktor lingkungan tersebut meliputi tersedianya udara bersih dan air bersih, tidak terjadi banjir dan longsor akibat tutupan hutan yang terbuka, terjaganya satwa dan tumbuhan. Masyarakat yang tergabung pada MPA menyadari bahwa lingkungan yang terjaga 


\section{DARJO et al. Strategi Peningkatan Efektivitas Masyarakat Peduli Api (MPA)...}

menjadi kunci kelestarian ekosistem dan mata pencahariannya.

Sebanyak 70 dari 75 anggota MPA yang menjadi responden penelitian ini bekerja sebagai petani, baik itu sebagai pekerjaan utama ataupun sampingan. Latar belakang tersebut juga menjadi alasan partisipasi MPA dalam pengendalian kebakaran hutan cenderung dominan dipengaruhi faktor lingkungan. Lahan pertanian yang dikelola tidak jauh dari kawasan hutan, menjadikan kepedulian anggota MPA terhadap kelestarian hutan tinggi. Hal ini disebabkan oleh karena ketika kebakaran hutan terjadi dan dibiarkan, maka lama-kelamaan akan merusak juga lahan pertanian yang dikelolanya. Oleh karena itu, dapat dikatakan dengan menjaga kawasan hutan tidak terbakar maka lahan pertanian juga terjaga. Kondisi ini sependapat dengan Fadlillah et al., (2017) dalam penelitiannya menyatakan ketika anggota MPA mengganggap bahwa kegiatan pengendalian kebakaran hutan merupakan sesuatu yang mereka butuhkan dan untuk kepentingan diri mereka sendiri, maka secara otomatis mereka berpartisipasi dalam proses dan praktiknya.

Landasan adanya MPA adalah Perdirjen PPI nomor 3 tahun 2018 yang mengatur tentang Pembentukan dan Pembinaan MPA. Peraturan ini hadir menggantikan Perdirjen PHKA nomor 2 tahun 2014 tentang pembentukan dan pembinaan MPA. Perdirjen PPI nomor 3 tahun 2018 merupakan peraturan untuk memperjelas kedudukan MPA dan mengatur sistem di dalam MPA. Terdapat lima elemen atau kriteria dalam Perdirjen PPI nomor 3 tahun 2018, meliputi (1) pembinaan; (2) organisasi; (3) monitoring dan evaluasi; (4) pelaporan; dan (5) pendanaan (Tabel 1). 
Tabel 1. Implementasi Perdirjen PPI nomor 3 tahun 2018 menurut stakeholder

\begin{tabular}{|c|c|c|c|}
\hline Kriteria & Kesesuaian & $\begin{array}{c}\text { Sesuai } \\
(\%)\end{array}$ & $\begin{array}{c}\text { Belum Sesuai } \\
(\%)\end{array}$ \\
\hline $\begin{array}{l}\text { Pembinaan } \\
\text { (supervisi, pelatihan, pembekalan, inhouse training, } \\
\text { on the job training, studi banding, pengembangan } \\
\text { inovasi, bimbingan teknis, penguatan kelembagaan, } \\
\text { pendampingan, fasilitasi, dan penyuluhan) }\end{array}$ & $1 \mathrm{kali} / \mathrm{tahun}$ & 83.48 & 16.52 \\
\hline $\begin{array}{l}\text { Organisasi } \\
\text { (ketua, sekretaris merangkap bendahara, dan kepala } \\
\text { regu) }\end{array}$ & Ada & 79.26 & 20.74 \\
\hline $\begin{array}{l}\text { Monitoring dan Evaluasi } \\
\text { (tingkat desa, kecamatan, kabupaten, provinsi, dan } \\
\text { UPT) }\end{array}$ & Ada & 49.63 & 50.37 \\
\hline $\begin{array}{l}\text { Pelaporan } \\
\text { (kepada kepala desa, UPT, kesesuaian format } \\
\text { laporan) }\end{array}$ & Ada & 65.43 & 34.57 \\
\hline \multirow{2}{*}{$\begin{array}{l}\text { Pendanaan } \\
\text { (berasal dari pusat, pemda, CSR perusahaan, LSM, } \\
\text { swadaya dan berupa uang, pelatihan, dan sarana- } \\
\text { prasarana) } \\
\text { Rerata }\end{array}$} & Ada & 54.17 & 45.83 \\
\hline & & 66.39 & 33.61 \\
\hline
\end{tabular}

Keterangan: $\mathrm{n}=27$

Pada Tabel 1 menunjukkan bahwa sebanyak $66,39 \%$ responden menilai Perdirjen PPI nomor 3 tahun 2018 telah diimplementasikan di lapangan sesuai dengan yang tertuang pada peraturan, sedangkan sisanya $33,61 \%$ masih belum diimplementasikan. Masih adanya ketidaksesuaian dengan kriteria yang ada menunjukkan adanya gap. Gap merupakan ketidaksesuaian tujuan atau harapan (Fadllillah et al., 2017). Munculnya gap menunjukkan bahwa ada tujuan yang hendak dicapai dengan berbagi kriteria yang dibuat, namun implementasi di lapangan belum seluruhnya dilakukan. Belum diimplementasikannya secara menyeluruh peraturan tersebut di lapangan dapat disebabkan oleh berbagai hal, terutama karena adanya keterbatasan sumber daya baik manusia ataupun anggarannya.

Pada kriteria pembinaan memiliki kesesuaian yang tertinggi dibanding kriteria lainnya. Kondisi ini menjelaskan bahwa butir kegiatan pada kriteria pembinaan hampir seluruhnya telah diterapkan dan dilaksanakan. Pada kriteria tersebut, hanya kegiatan studi banding saja yang mayoritas menjawab belum dilakukan. Hal ini dikarenakan pada saat ini Kementerian Lingkungan Hidup dan Kehutanan melalui Direktorat Jenderal Pengendalian Perubahan Iklim (DJPPI) berfokus pada memperbanyak pembentukan MPA di 


\section{DARJO et al. Strategi Peningkatan Efektivitas Masyarakat Peduli Api (MPA)...}

berbagai wilayah yang rawan terjadi kebakaran guna menekan luas karhutla dan dapat lebih antisipatif serta responsif di tingkat tapak. Hal ini terlihat jelas pada BPPIKHL JBN selaku unit pelaksana teknis DJPPI bahwa telah dianggarkan kegiatan pembentukan dan pembinaan MPA pada dua tahun terakhir, termasuk di tahun 2020 ini.

Sedangkan kriteria dengan nilai terendah berada pada kriteria pendanaan, masih terdapat gap/ketidaksesuaian sebesar 45,83\%. Hal ini menunjukkan pendanaan yang dilakukan sampai saat ini masih dapat terus ditingkatkan untuk mendukung optimalisasi pengendalian kebakaran hutan yang dilakukan oleh MPA. Selama ini pendanaan kepada MPA bergantung pada anggaran dari pemerintah pusat yang disalurkan melalui UPT atau pemangku kawasan yag ada dan swadaya masyarakat. Berdasarkan wawancara, diketahui bahwa bentuk pendanaan yang diberikan sebagian besar berupa pelatihan. Sedangkan uang seringkali diberikan untuk mendukung upaya pemadaman di lapangan. Sementara sarana prasarana yang diberikan kepada MPA dapat dikatakan masih minim, karena belum merata disemua MPA diberikan pelengkapan penunjang pengendalian kebakaran hutan.

\section{Strategi peningkatan efektivitas MPA} melalui analisis SWOT

Efektivitas MPA dapat ditingkatkan dengan menetapkan strategi dengan mempertimbangkan dari sisi internal dan sisi eksternal, salah satunya melalui analisis SWOT (Elyarni dan Hermanto, 2016; Rangkuti, 2018). Rangkuti (2018) menambahkan bahwa analisis SWOT membandingkan faktor eksternal (peluang dan ancaman) dengan faktor internal (kekuatan dan kelemahan), sehingga diperoleh strategi yang komprehensif. Hasil analisis SWOT pada penelitian ini disajikan dalam Gambar 6. 


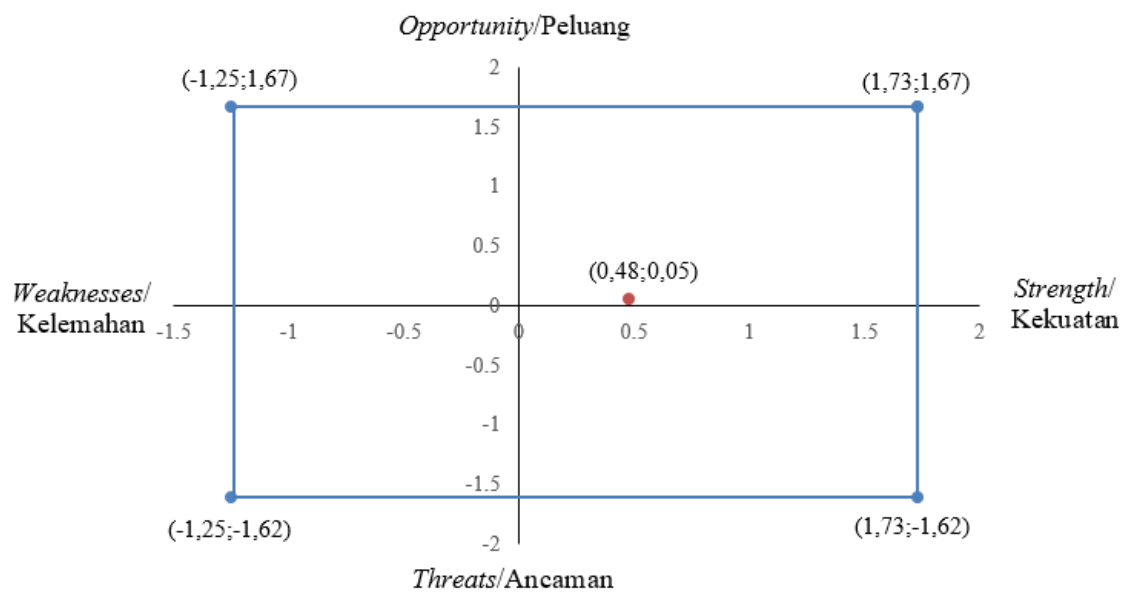

Gambar 6. Diagram cartesius analisis SWOT MPA

Berdasarkan hasil analisis (Rangkuti, 2018). Strategi yang harus sebagaimana terlihat pada Gambar 6, dapat diterapkan pada kondisi ini adalah diketahui bahwa MPA memiliki nilai mendukung kebijakan pertumbuhan yang kekuatan sebesar 1,73 dan nilai kelemahan agresif (growth oriented strategy). Hal ini sebesar 1,25 (Gambar 6), sehingga menunjukkan bahwa MPA di Provinsi Bali diperoleh nilai IFAS (Internal Strategic khususnya memiliki kekuatan dan peluang Factor Analisis Summary) sebesar 0,48. untuk terus dikembangkan dan ditingkatkan Selain itu, MPA juga memiliki nilai peluang sebesar 1,67 dan nilai ancaman sebesar 1,62, maka diperoleh nilai EFAS (Eksternal Strategic Factor Analisis Summary) sebesar 0,05. IFAS dan EFAS MPA bernilai positif, sehingga terbentuk koordinat di kuadran I.

Rangkuti (2018) menjelaskan bahwa keberadaan hasil IFAS dan EFAS di kuadran I maka artinya mendukung strategi agresif. Strategi agresif merupakan situasi sangat menguntungkan bagi perusahaan karena memiliki peluang dan kekuatan terutama dalam kaitannya pengendalian kebakaran hutan.

Berdasarkan faktor internal dan eksternal MPA di Provinsi Bali dapat dibuat suatu analisis strategi dengan melihat keterkaitan di antara kedua faktor tersebut (Syaputra, 2018). Analisis ini menjadi salah satu upaya untuk mengidentifikasi kemungkinan rencana dan usaha yang dapat dilakukan untuk mengatasi permasalahan pada MPA. Berdasarkan hasil analisis SWOT, maka strategi mengatasi permasalahan pada MPA di Provinsi Bali 


\section{DARJO et al. Strategi Peningkatan Efektivitas Masyarakat Peduli Api (MPA)...}

adalah Strategi S-O (StrengthsOpportunities). Strategi S-O yang dapat dilakukan adalah sebagai berikut:

a. Mendetailkan SOP, aturan, dan regulasi yang mengatur terkait MPA secara komprehensif.

b. Memperbanyak sarana-prasarana bagi MPA untuk pengendalian kebakaran hutan dengan memanfaatkan peluang kerja sama dengan pihak lain.

c. Memfasilitasi terbentuknya forum yang mewadahi MPA seluruh wilayah, agar saling terhubung dan memudahkan dalam komunikasi.

d. Memfasilitasi MPA untuk meningkatkan kapasitas SDM melalui kegiatan sosialisasi, bimbingan teknis, pelatihan, patroli, pengenalan teknologi pengendalian kebakaran hutan.

e. Penggiatan penanaman dengan jenis yang selalu hijau/go green dengan komposisi jenis yang beragam.

\section{SIMPULAN}

Berdasarkan hasil analisis, diperoleh kesimpulan bahwa Masyarakat (MPA dan non MPA) memberikan persepsi positif terhadap penyebab kebakaran hutan dan dampak kerugian akibat kebakaran hutan. Masyarakat (MPA dan non MPA) mempersepsikan faktor alam berupa kemarau panjang dan faktor manusia berupa membuang puntung rokok sebagai penyebab utama terjadinya kebakaran hutan. Masyarakat MPA dan non MPA juga sepakat bahwa lingkungan merupakan yang paling terdampak dan dirugikan akibat terjadinya kebakaran hutan. Partisipasi MPA dalam pengendalian kebakaran hutan menunjukkan hasil aktif dan partisipasi tertinggi melalui kegiatan pemadaman, dengan faktor yang paling mempengaruhi partisipasi adalah faktor lingkungan. Implementasi Perdirjen PPI nomor 3 tahun 2018 sebesar 66,39\%, sehingga masih terdapat gap. Nilai tersebut menunjukkan keberadaan MPA di Provinsi Bali dapat dikatakan belum efektif sepenuhnya dalam melakukan pengendalian kebakaran hutan, karena belum diimplementasikan secara menyeluruh. Strategi peningkatan efektivitas MPA berupa S-O (StrengthsOpportunities), yang mengindikasikan bahwa MPA memiliki kekuatan untuk memanfaatkan. Efektivitas MPA dapat ditingkatkan dengan adanya dukungan nyata melalui regulasi yang jelas, alokasi anggaran yang ditingkatkan, dan peningkatan kapasitas SDM di tingkat tapak, serta penggiatan kegiatan penghijauan di sekitar kawasan rawan 
kebakaran dengan jenis/spesies yang

beragam dan selalu hijau/go green.

\section{DAFTAR PUSATAKA}

Alawi, M. A. (2017). Kebakaran 3,5 Hutan Poko Diduga karena Puntung Rokok. https://regional.kompas.com/read/201 7/07/07/23202051/kebakaran.3.5.huta n.poko.diduga.karena.puntung.rokok diakses pada 2 Juli 2020.

Alisjahbana, A S., \& Jonah, M. B. (2017). Forestry, Forest Fires, and Climate Change in Indonesia. Bulletin of Indonesian Economic Studies, 53 (2): 111-136.

BNPB. (2013). Rencana Kontinjensi Nasional Menghadapi Ancaman Bencana Asap Akibat Kebakaran Hutan dan Lahan. Jakarta.

BPPIKHL Jawa Bali Nusa Tenggara. (2020). Statistik Tahun 2019. Kementerian Lingkungan Hidup dan Kehutanan. Bali.

David, L. A. G., Mohammad, A. S., Kristell, H., Bruno, L., Sean, S., Martin, W., Miriam, E M., Elis, M., Husna, Y., Ruth, D., Louis V., Daniel M., Robert, N., Peter, H., \& Douglas, S. (2014). Major atmospheric emission from peat fires in Southeast Asia during non-drought years: evidence from the 2013 Sumatran fires. Sci Rep 4: 6112.Edward., Scott, A., Felix, H. 2015. Hazy Days: Forest Fires and the Politics of Environmental Security in Indonesia. Journal of Current Southeast Asian Affairs, 34 (3): 65-94.

Edward., Scott, A., \& Felix, H. (2015). Hazy Days: Forest Fires and the Politics of Environmental Security in Indonesia. Journal of Current Southeast Asian Affairs, 34 (3): 6594.
Elyarni, R., \& Hermanto. (2016). Analisis SWOT Terhadap Strategi Pemasaran Layanan SAP Express pada PT. SAP. Jurnal Metris, 17: 81-88.

Evayanti, T., \& Zulkarnaini. (2014). Partisipasi Organisasi Masyarakat Peduli Api (MPA) Terhadap Pencegahan dan Pengendalian Kebakaran Hutan dan Lahan di Kabupaten Pelalawan. Jurnal Ilmu Lingkungan, 8 (1): 1-11.

Fadlillah, N., Sambas, B., \& Tutut, S. (2017). Pengendalian Kebakaran Hutan oleh Masyarakat Peduli Api (MPA) di Taman Nasional Gunung Ciremai. Media Konservasi, 21 (3): 216-224.

Földi, L., \& Rajmund, K. (2016). Characteristics of Forest Fires and Their Impact on the Environment. AARMS, 15 (1): 5-17.

Harrison, M. E., Susan E. P., \& Suwido, H. L. (2009). The Global Impact of Indonesian Forest Fires. Biologist 56 (3): 156-163.

Miettinen, J., Chenghua, S., \& Soo, C. L. (2017). Fire Distribution in Peninsular Malaysia, Sumatra and Borneo in 2015 with Special Emphasis on Peatland Fires. Environmental Management, 60 (4): 747-757.

Nursoleha, P., Eva, B., \& Satyanta, P. (2014). Zonasi tingkat kerawanan kebakaran hutan di Taman Nasional Gunung Ceremai (TNGC) berbasis sistem informasi geografi (SIG). GeoImage, 3 (1): 1-4.

Peraturan Direktur Jenderal Perlindungan Hutan dan Konservasi Alam nomor 2 tahun 2014 tentang Pembentukan dan pembinaan Masyarakat Peduli Api.

Peraturan Direktur Jenderal Pengendalian Perubahan Iklim nomor 3 tahun 2018 tentang Pembentukan dan pembinaan Masyarakat Peduli Api. 


\section{DARJO et al. Strategi Peningkatan Efektivitas Masyarakat Peduli Api (MPA)...}

Rangkuti, F. (2018). Analisis SWOT Teknik Membedah Kasus Bisnis. Cetakan Dua Puluh Empat. PT. Gramedia. Jakarta.

Rasyid, F. (2014). Permasalahan dan Dampak Kebakaran Hutan. Jurnal Lingkar Widyaiswara, 1 (4): 47-59.

Rezkisari, I. (2017). Puntung Rokok Jadi Penyebab Kebakaran Hutan Nagan Aceh.

https://www.republika.co.id/berita/na sional/daerah/17/07/25/otmtt1328-

puntung-rokok-jadi-penyebab-

kebakaran-hutan-nagan-aceh diakses pada 2 Juli 2020.

Saharjo, B H., Lailan, S., Ati, D N., Erianto, I P., Robi, D W., \& Wardana. (2018). Pengendalian Kebakaran Hutan dan Lahan di Wilayah Komunitas Terdampak Asap. IPB Press. Bogor.

Saharjo, B. H., \& Guntala, W. (2017). Persepsi Masyarakat dalam Upaya Pengendalian Kebakaran Hutan di Taman Nasional Gunung Ciremai. Jurnal Silvikultur Tropika, 08 (2): 141-146.

Sawerah, S., Pudji, M., \& Prabowo, T. (2016). Partisipasi Masyarakat dalam Pencegahan Kebakaran Lahan Gambut di Kabupaten Mempawah, Provinsi Kalimantan Barat. Jurnal Penyuluhan, 12 (1): 89-102.

Suyatra, P. (2017). Api Puntung Rokok Ludeskan Dua Hektare Hutan Lindung di Gerokgak. https://baliexpress.jawapos.com/read/ 2017/09/05/11805/api-puntungrokok-ludeskan-dua-hektare-hutanlindung-di-gerokgak diakses pada 2 Juli 2020.

Syaputra, M. (2018). Identifikasi Permasalahan dan Strategi dalam Pengelolaan Sampah di Jalur Pendakian Taman Nasional Gunung
Rinjani. Jurnal Sangkareang Mataram, Vol 4 (2): 30-33.

Tacconi, L. (2003). Kebakaran Hutan di Indonesia: Penyebab, Biaya dan Implikasi Kebijakan. Center for International Forestry Research (CIFOR) Occasional Paper 38 (i). Bogor.

Tanjung, C. A. (2019). Buang Puntung Rokok, Sabri Jadi Tersangka Kebakaran Hutan. https://news.detik.com/berita/d4380159/buang-puntung-rokok-sabrijadi-tersangka-kebakaran-hutan diakses pada 2 Juli 2020.

Wade, C., \& Carol, T. (2007). Psikologi. Edisi 9 Jilid 1. Erlangga. Jakarta. 